\title{
Livelihood Security through Participations of Tribal Farm Women in Rice-Based Farming System in Bastar Plateau of Chhattisgarh
}

\author{
S.K. Painkra ${ }^{1}$, P.S.Netam ${ }^{2}$, S.P.Singh ${ }^{3 *}$ and G. R. Rathia ${ }^{4}$ \\ ${ }^{1}$ College of Agriculture and Research Station, Raigarh (C.G.), India \\ ${ }^{2} S G$ CARS, Jagdalpur (C.G.), India \\ ${ }^{3}$ Krishi Vigyan Kendra, Raigarh-496001 (C.G.) \\ ${ }^{4}$ College of Agriculture \& Research Station, Raigarh (C.G.). ${ }^{4}$ \\ Indira Gandhi Krishi Viswavidyalaya, Raipur (C.G.), India \\ *Corresponding author
}

\begin{abstract}
A B S T R A C T
The study highlights the extent of tribal farm women's actively participation through various farm and household activities for livelihood security to their family life in rice based farming system. A study was undertaken in Narayanpur district in Bastar plateau of Chhattisgarh state to analyze the livelihood security through tribal farm women in rice based farming system and identify different farm development activities. The participations of tribal farm women in Narayanpur district mainly from rice cultivation, horticulture and animal husbandry activities were taken for the study. The results further revealed that the income may be generated through different farm activities by enhancement in empowerment of farm women in rice based farming system. The data showed that majority of the tribal farm women 56.66 per cent were actually involved in rice transplanting under pre sowing activities 86.00 per cent in weeding and 95.33 per cent drying and cleaning under intercultural, harvest and post harvest activities respectively as well as Illiteracy was perceived as the top most constraints by 89.33 per cent respondent's empowerment through participation in farm activities for income generation for livelihood security in rice -based farming system in the study area. For betterment of livelihood security in their family life, basic facilities and requirements to be provided for raising the employment and generating income through farm different developmental programmes including household enterprises activities along with actively participation of tribal farm women.
\end{abstract}

\section{Keywords}

Tribal livelihood, Tribal farm women, Empowerment, Rice-based farming system

Article Info

Accepted:

10 April 2020

Available Online:

10 May 2020

\section{Introduction}

It shows the study of history that it was the tribal women who first domesticated crop plants thereby initiated the arts and science of farming (Swaminathan, 1985). The involvement of tribal women, especially in agriculture is an old age practice. Tribal Farmwomen play a significant role in agriculture along the side of their men folk sharing the burden of farm works, care of animals and poultry keeping in addition to 
their responsibilities along the side of their men folk sharing under the household as home maker. Enhancing women's economic status is an important strategy for improving the welfare of entire the family. Socioeconomic upliftment and improvement of livelihood condition of the people can be directly linked with empowering rural women for agricultural sustainability and efficient use of available farm resources to make them self sufficient in term of employment generation.

Narayanpur is known as primitive tribes' district in India. Mariya and Muriya are main tribes of the district. According to census survey (2011), total population of the distrct is 139820. In which more than 70 per cent populations are come under tribal community. Rice is cultivated as main crop and secondary crop are maize, millets (Kodo, kutki, finger and fox millets), oilseed and pulses under raifed situations. Farmers do not adopt advance agricultural technology in the district. Due to which, production and productivity is very low as compare to other district of Chhattisgarh state. There Ricebased farming is productive enterprises to generate of employment, family income, utilize natural resources, and ensure food and nutritional security in Narayanpur district in Bastar plateau (Chhattisgarh). In this plateau, agricultural is a main source of occupation and the tribal farm women are actively involved in several farm activities in rice based farming system for their livelihood security. Thus, the importance role and contribution of farm women to upliftment their household in rice based farming system. do not Therefore, extension services may accordingly be turned to fully integrated them for their enhancing productivity in rice cultivation, so that their standard of living pattern may be uplifted from below poverty line. In this context a study was undertaken in Narayanpur district Bastar plateau of Chhattisgarh with the following objectives:
1. To study the livelihood security and involvement of tribal farm women in different activities in rice based farming system.

2. To identify the constraints in empowerment of tribal farmwomen's in the study area.

\section{Materials and Methods}

The study was conducted in Narayanpur block of Narayanpur district, Chhattisgarh. A total of 150 tribal farm women as respondents were selected from five selected village panchayats viz., Bijli, Palki, Brehbeda, Kudkajhore and Garhbengal through simple random sampling methods. The data were collected through personal interview techniques with pre-tested interview scheduled and analyzed for percentage and mean score. Regarding the involvements of tribal farm women different activities in rice based farming, the response were recorded from tribal farm women in 3-point scale i.e. actively involved (2 scores), moderately involved (1 score) and not involved (0 scores). The responses ranked on the basis of mean scored were obtained.

\section{Results and Discussion}

In Narayanpur district (C.G.), the livelihood pattern of tribal farm women in rice based farming system mainly from rice cultivation, horticulture and animal husbandry activities were taken to the study. Therefore, it is very important to know the involvement of tribal women in these three activities for their livelihood security. The relating to the involvement the tribal farmwomen's in rice based farming system with respect to three major areas, viz., agriculture (rice cultivation), horticulture (vegetable cultivation) and animal husbandry (Dairy and poultry) activities were taken at particular study area. 
The data presented in Table 1. Participation of respondents in rice cultivation was studied in three selected sub-areas namely, pre sowing and sowing activities, inter cultural activities and harvest and post harvest activities. The data revealed that majority of tribal women (56.66\%) were actively involved in transplanting followed by manure application and nursery raising i. e. $44.66 \%$ and $26.26 \%$ respectively under Pre sowing \& sowing activities. This type of result was also observed by Beohar et al., (1999), Hussain et al., (2011), Kumari et al., (2016) and Mohanta (2017). In case of inter cultural activities, majority of respondent were actively involved in weeding $(86.00 \%)$ and thinning \& gap filling $(80.00 \%)$ in rice cultivation activities as well as in Harvest \& Post harvest activities greater percentages of tribal farmwomen were engaged in operation like drying \& cleaning $(95.33 \%)$, harvesting (93.33\%), winnowing (92.00\%) and threshing $(23.33 \%)$, whereas, only 4.66 per cent respondents were actively involved in treating grains with insect repellants. Having showed the data of this table, it may be reason behind that the tribal women are more aware to their house livelihood upliftment and it is possible to participate in farming activities so that income may be generated because agriculture is main occupation of the study area. These findings are in line with the findings of Bhople and Patki (1992), Mohanty (1993), Gopalappa (1997) and Das (1999).

The data with respect to horticultural activities i. e. vegetable cultivation is presented in Table 2. Shows that majority of the tribal women were actively involved in weeding (84.66\%), Harvesting $(80.66 \%)$, Thinning \& gap filling $(75.33 \%)$, Uprooting \& transplanting $(65.33 \%)$, Seed sowing \& watering the nursery $(63.33 \%)$ Nursery bed preparation $(50.66 \%)$, Collection of vegetable seeds (41.33\%) whereas only (3.33\%) respondents actively involved in Preparation of value added products in the study area. The reason behind that the more participation of tribal women in horticultural activities due to maximum horticultural crops grown near at house or farm as well as their cultural habitation also. They know that it is the good source of secondary income which may be taken round the year from vegetables, where irrigation facilities are available as well as income is achieved earlier as compare to rice cultivation. The tribal farm women belong to low income group and income obtained from small holding is insufficient for a reasonably comfortable living. The poor involvement of tribal farm women in preparation of value added product might be due to illiteracy, lack of awareness and exposure to different training programmes. The same type of findings was observed by Gidda Reddy (2003).

The mean score and rank for involvement in dairy activity presented in table 3 revealed that the first four areas in which respondents participated actively were care and management of animals, Maintenance of cattle shed, Fodder collection and Feeding of animals with mean scores of 1.13, 1.08, 1.04 and 0.98 respectively. Only Marketing of milk and Milking cow mean score was 0.16 and 0.08 with fifth and sixth ranks in the study area. The rank was very low in case of Milking of cow and Marketing of milk. On the basis of observations like less use of milk in family due to their cultural habitation as well as unawareness about marketing of dairy. The results supports the findings of Sharma et al., (1989), Shashikala et al., (1990 and Jamal (1994) and Chouhan (2009).

Majority of the tribal women under poultry activities (42.66\%) actively involved in maintenance of birds cages followed by Feeding of birds, Care and management of birds and Selling eggs/birds i. e. (30.66\%), $(30.00 \%)$ and $(27.33 \%)$ respectively. The 
results shows that there is no more management in case of poultry keeping and it is possible along with housekeeping, which is good source of income for household, which may be easily adopted due to their cultural habitant. The same types of findings was also reported by Saikia et al., (1986) and Waghmare and Chaudhari (1989).

The constraints in empowerment as perceived by tribal farm women are furnished in Table 4. It was evident that Illiteracy was perceived as the top most constraints as (89.33\%) respondents agreed with it as many as $(79.33 \%)$ respondents opined that lack of practical knowledge as the second most important hindrance in empowerment. The other constraints perceived by the respondents in order of importance were lack of exposure to training programme $(34.00 \%)$, male dominancy in decision making activities (48.66\%), Problems of financial supports (34.00\%). Only (26.00\%) respondents expressed heavy works load due to duel responsibility as one of the constraints in empowerment for livelihood security in rice based farming system. There was also found literacy rate of very low, lack of awareness in women education, low marriage of tribal girls due to their socio cultural phenomena in the society.

Table.1 Distribution of respondents on the basis of involvement in rice cultivation activities

\begin{tabular}{|c|c|c|c|c|c|}
\hline $\begin{array}{l}\text { Pre sowing \& sowing } \\
\text { activities }\end{array}$ & AI & MI & NI & $\begin{array}{l}\text { Mean } \\
\text { Score }\end{array}$ & Rank \\
\hline Land preparation & $11(7.33)$ & $42(28.00)$ & $97(64.66)$ & 0.43 & IV \\
\hline Manure application & $67(44.66)$ & $50(33.33)$ & $33(22.00)$ & 1.22 & II \\
\hline $\begin{array}{l}\text { Seed selection and } \\
\text { treatment }\end{array}$ & $15(10.00)$ & $24(16.00)$ & $111(74.00)$ & 0.36 & V \\
\hline Sowing of seed & $16(10.66)$ & $21(14.00)$ & $113(75.33)$ & 0.35 & VI \\
\hline Nursery raising & $40(26.26)$ & $45(30.00)$ & $65(43.43)$ & 0.83 & III \\
\hline Transplanting & $85(56.66)$ & $48(28.66)$ & $17(11.33)$ & 1.45 & I \\
\hline \multicolumn{6}{|l|}{ Intercultural activities } \\
\hline Weeding & $129(86.00)$ & $15(10.00)$ & $06(4.00)$ & 1.82 & $\mathrm{I}$ \\
\hline Thinning \& gap filling & $121(80.66)$ & $20(13.33)$ & $09(6.00)$ & 1.74 & II \\
\hline Irrigation & $10(6.66)$ & $17(11.33)$ & $123(82.00)$ & 0.24 & III \\
\hline Pesticide application & $00(0.00)$ & $05(3.33)$ & $145(96.66)$ & 0.03 & V \\
\hline Fertilizer application & $09(6.00)$ & $15(10.00)$ & $126(84.00)$ & 0.22 & IV \\
\hline \multicolumn{6}{|l|}{$\begin{array}{lc}\text { Harvest } \underset{\text { \& }}{\&} \text { Post } \\
\text { harvest activities }\end{array}$} \\
\hline Harvesting & $140(93.33)$ & $10(6.66)$ & $00(0.00)$ & 1.93 & II \\
\hline Threshing & $35(23.33)$ & $93(62.00)$ & $22(14.66)$ & 1.08 & $\mathrm{~V}$ \\
\hline Winnowing & $138(92.00)$ & $12(8.00)$ & $00(0.00)$ & 1.92 & III \\
\hline Drying \& cleaning & $143(95.33)$ & $07(4.66)$ & $00(0.00)$ & 1.95 & I \\
\hline $\begin{array}{l}\text { Treating grains with } \\
\text { insect repellants }\end{array}$ & $07(4.66)$ & $12(8.00)$ & $131(87.33)$ & 0.17 & VI \\
\hline Storing grains & $128(85.33)$ & $10(6.66)$ & $12(8.00)$ & 1.77 & IV \\
\hline
\end{tabular}

(Figures in the parentheses represent percentage)

$\mathrm{AI}=$ Actively Involved $\mathrm{MI}=$ Moderately Involved $\mathrm{NI}=$ Not Involved 
Table.2 Distribution of respondents on the basis of involvement in horticultural (vegetable cultivation) activities

\begin{tabular}{|l|l|l|l|l|l|}
\hline Activities & AI & MI & NI & Mean Score & Rank \\
\hline Collection of vegetable seeds & $\begin{array}{l}62 \\
(41.33)\end{array}$ & $47(31.33)$ & $\begin{array}{l}41 \\
(27.33)\end{array}$ & 1.14 & VII \\
\hline Nursery bed preparation & $\begin{array}{l}76 \\
(50.66)\end{array}$ & $30(20.00)$ & $\begin{array}{l}44 \\
(29.33)\end{array}$ & 1.21 & VI \\
\hline $\begin{array}{l}\text { Seed sowing \& watering the } \\
\text { nursery }\end{array}$ & $\begin{array}{l}95 \\
(63.33)\end{array}$ & $29(19.33)$ & $\begin{array}{l}26 \\
(17.33)\end{array}$ & 1.46 & V \\
\hline Uprooting \& transplanting & $\begin{array}{l}98 \\
(65.33)\end{array}$ & $32(21.33)$ & $\begin{array}{l}20 \\
(13.33)\end{array}$ & 1.52 & IV \\
\hline Thinning \& gap filling & $\begin{array}{l}113 \\
(75.33)\end{array}$ & $22(14.66)$ & $\begin{array}{l}15 \\
(10.00)\end{array}$ & 1.65 & III \\
\hline Weeding & $\begin{array}{l}127 \\
(84.66)\end{array}$ & $15(10.00)$ & $08(5.33)$ & 1.79 & I \\
\hline Harvesting & $\begin{array}{l}121 \\
(80.66)\end{array}$ & $18(12.00)$ & $11(7.33)$ & 1.73 & II \\
\hline $\begin{array}{l}\text { Preparation of value added } \\
\text { products }\end{array}$ & $05(3.33)$ & $15(10.00)$ & $\begin{array}{l}130 \\
(86.66)\end{array}$ & 0.16 & VIII \\
\hline
\end{tabular}

(Figures in the parentheses represent percentage)

$\mathrm{AI}=$ Actively Involved $\quad \mathrm{MI}=$ Moderately Involved $\mathrm{NI}=$ Not Involved

Table.3 Distribution of respondents on the basis of involvement in animal husbandry (dairy and poultry) activities

\begin{tabular}{|c|c|c|c|c|c|}
\hline Dairy Activities & AI & MI & NI & Mean Score & Rank \\
\hline Milking cow & $03(2.00)$ & $07(4.66)$ & $\begin{array}{l}140 \\
(93.33)\end{array}$ & 0.08 & VI \\
\hline Feeding animals & $53(35.33)$ & $42(28.00)$ & $55(36.66)$ & 0.98 & IV \\
\hline Maintenance of cattle shed & $69(46.00)$ & $24(16.00)$ & $57(38.00)$ & 1.08 & II \\
\hline Fodder collection & $61(40.66)$ & $35(23.33)$ & $54(36.00)$ & 1.04 & III \\
\hline $\begin{array}{l}\text { Care \& management of } \\
\text { animals }\end{array}$ & $69(46.00)$ & $32(21.33)$ & $49(32.66)$ & 1.13 & I \\
\hline Marketing of milk & $07(4.66)$ & $11(7.33)$ & $\begin{array}{l}132 \\
(88.00)\end{array}$ & 0.16 & V \\
\hline \multicolumn{6}{|l|}{ Poultry Activities } \\
\hline Feeding of birds & $46(30.66)$ & $53(35.33)$ & $51(34.00)$ & 0.96 & II \\
\hline Maintenance of birds cages & $64(42.66)$ & $47(31.33)$ & $39(26.00)$ & 1.16 & I \\
\hline $\begin{array}{l}\text { Care and management of } \\
\text { birds }\end{array}$ & $45(30.00)$ & $50(33.33)$ & $55(36.66)$ & 0.93 & III \\
\hline Selling eggs/birds & $41(27.33)$ & $44(29.33)$ & $65(43.33)$ & 0.84 & Iv \\
\hline
\end{tabular}

(Figures in the parentheses represent percentage)

$\mathrm{AI}=$ Actively Involved $\quad \mathrm{MI}=$ Moderately Involved $\mathrm{NI}=$ Not Involved 
Table.4 Constraints perceived by tribal farmwomen for income generating activities in rice based farming system

\begin{tabular}{|c|c|c|c|}
\hline Constraints & Frequency & percentage & Rank \\
\hline Illiteracy & 134 & 89.33 & I \\
\hline Lack of practical knowledge & 119 & 79.33 & II \\
\hline Lack of exposure to training programme & 94 & 62.66 & III \\
\hline Problems of financial supports & 51 & 34.00 & $\mathrm{~V}$ \\
\hline $\begin{array}{l}\text { Male dominancy in decision making } \\
\text { activities }\end{array}$ & 73 & 48.66 & IV \\
\hline $\begin{array}{l}\text { Heavy works load due to duel } \\
\text { responsibility }\end{array}$ & 39 & 26.00 & VI \\
\hline
\end{tabular}

(* The added percentage is more than 100 since multiple response were allowed)

Findings of the above study it was concluded that the women participations is very important in farm activities in rice based cropping system to increase the employment and income generation. For better standard of living in their family life, improved crops and livestock management technologies as well as household activities, input and services, awareness about training and education, organized marketing and credit facilities is to be provided by different line department like agriculture, horticulture, veterinary and allied sectors as well as it should be organized training programme actively participation with farm women in the field of agriculture including household enterprises as well as activities is to in proper time. so that the more employment opportunities and income could be generated by the tribal farm women to their family.

\section{References}

Beohar, B. B., Sarawgi, A. K. and Chaudhary, A. K. (1999). Women's contribution in paddy cultivation: A case study of village of Chhattisgarh Region of Madhya Pradesh. Indian J. of Agric. Econ., 54 (3): 323-324.

Bhople, R. S. and Patki, A. (1992). Correlates of role performance and training needs of farm women labour. J. of Rural
Development, 11 (1): 49-58.

Chouhan, N. M. (2009) Participation of tribal farm women in animal husbandry, paper presented in: seminar on Participatory approach in rural development on August 31, 2009 at JAU, Junagarh, Gujrat.

Das, L. (1999). A study on Multidimensional Role in Farm and Home and Health Status of Tribal Women in Kalahandi District of Orissa. Ph. D. Thesis, BHU, Varanasi.

Gidda Reddy P. (2003). Farming Performance of farm women. Concept Publishing Company, New Delhi.

Gopalappa, D.V. (2003). Diversified Agriculture and Rural Women. Yojana, 41 (11): 27-32.

Hussain, B., Hussain, N. A. and Yaseen, W. M. (2011) An Empirical Analysis of Women Participants in Farm Activities in Rural Kashmir. Eur. J. Business Manage. 3(5): 28-35.

Jamal, S. (1994). Women in dairy development. Cocept Publishing Company, New Delhi.

Kumari, A. R., meena, K. and Laxmikant (2016) Role of Farm Women in Rice Cultivation and Their Training Needs. J. Krishi Vigyan., 5(1): 96-100.

Mohanta (2017) Participation of Tribal Women in agriculture, International 
Journal of Science, Enviornment \& Technology, Vol. 6, No 1, 2017, pp. 745-750.

Mohanty, S. C. (1993) Social Position and Property Rights of Kutia Kondh Women. Adivasi, XXXIII (2): 16-20.

Saikia, P.D., Gogoi, K. and Lekharu, A. (1986). Indian Rural Women, Mittal Publications, New Delhi. pp.119-121.

Shashikala, S., Sundraswami, B. and Shankramurthy, H.G. (1990). Activities performance and Time Spent by Farm Women of Rainfed and Irrigated Areas, Indian Journal of Extension Education,
XXVI (3\&4): 59-63.

Swaminathan, M.S. (1985). Imparting Rural Women Users' Perspective to Agricultural Research and Development. Report of the Project Design Workshop on 'Women in Rice Farming System', held at IRRI, Los Banos, Philippines, April 10-13, pp. 14.

Waghmare, S.K. and Chaudhary N.V. (1989). Tribal women in agriculture, Metropolitan Book Co. Pvt. Ltd., New Delhi.

\section{How to cite this article:}

Painkra, S.K., P.S. Netam, S.P. Singh and Rathia, G.R. 2020. Livelihood Security through Participations of Tribal Farm Women in Rice -Based Farming System in Bastar Plateau of Chhattisgarh. Int.J.Curr.Microbiol.App.Sci. 9(05): 1395-1401. doi: https://doi.org/10.20546/ijcmas.2020.905.158 